\title{
Faktor-Faktor Yang Mempengaruhi Profitabilitas Pada Perusahaan Property and Real Estate Yang Terdaftar di BEI
}

\author{
Hanna limbong ${ }^{1}$, Deasy Arisandy Aruan ${ }^{2}$, Brando Silitonga ${ }^{3}$, Maulidanur Aceh ${ }^{4 *}$, Nofanyiu \\ Bernadett Br Samosir ${ }^{5}$ \\ $1,2,3,4,5$ Universitas Prima Indonesia \\ hannalimbong36@gmail.com, deasy.aruan@gmail.com ${ }^{*}$, brandosltng@gmail.com, \\ maulidan2017@gmail.com, nofanyiubernadett48@gmail.com
}

*Penulis Korespondensi

Diajukan : 3 Mei 2021

Disetujui : 23 Mei 2021

Dipublikasi : 1 Agustus 2021

\begin{abstract}
This study aims to determine the effect of liquidity, fixed assets, and firm size on profitability in property and real estate industry sub sectors listed in Indonesia Stock Exchange for the 2016-2019 period. The population in this study were all companies in property and real estate industry sub sector listed in Indonesia Stock Exchange for 2016-2019 period, amounting to 62 companies with a sample of 23 companies. The sampling technique used was purposive sampling. The method of analysis used in this research is the multiple linear regression method. This research uses quantitative research. This type of research used in this research is descriptive quantitative. The nature of research in this study is explanatory. The results of this study indicate that partially liquidity have no significant effect on profitability and fixed assets have no significant effect on profitability, while firm size have a negative and significant effect on profitability in the property and real estate sub-sector listed on the Indonesia Stock Exchange for the 2016-2019 period. Based on simultaneous liquidity, fixed assets, firm size have a significant effect on profitability in the property and real estate industry sub sector listed in Indonesia Stock Exchange for the 2016-2019 period.
\end{abstract}

Keywords: Liquidity, Fixed assets, firm Size and Profitability

\section{Latar belakang}

\section{PENDAHULUAN}

Profitabilitas sering digunakan untuk menganalisa perusahaan. Apabila profitabilitas perusahaan baik maka para investor dan kreditur dapat melihat sejauh mana perusahaan mampu menghasilkan laba dari penjualan. Adapun perkembangan perusahaan property and real estate yang sempat mengalami guncangan dimana terjadinya perang dagang yang melibatkan banyak negara dan mempengaruhi perekonomian global (Pujayanti, A. 2018) Kondisi dari dampak krisis ekonomi global dan perang dagang mengakibatkan perusahaan property and real estate mengalami perlambatan pada tekanan global, tekanan domestik baik itu nilai tukar dan kenaikan suku bunga, serta dampak lain yang terjadi ialah berkurangnya para investor yang ingin menginvestasikan modalnya di perusahaan property and real estate sehingga tingkat profitabilitas perusahaan semakin menurun.

Adapun faktor faktor yang mempengaruhi profitabilitas perusahaan property and real estate adalah likuiditas, ukuran perusahaan, umur perusahaan, pertumbuhan perusahaan, aktiva tetap, modal kerja, rasio kas. Beberapa hasil riset yang kami teliti tentang faktor-faktor yang mempengaruhi profitabilitas adalah hasil penelitian dari Novyanny, M. C., \& Turangan, J. A. (2017) Pengaruh likuiditas, ukuran perusahaan, umur perusahaan dan pertumbuhan perusahaan terhadap profitabilitas pada perusahaan jasa sektor perdagangan dan jasa investasi yang terdaftar pada Bursa Efek Indonesia dimana Variabel likuiditas, ukuran perusahaan, dan umur perusahaan 
tidak memiliki pengaruh terhadap profitabilitas perusahaan, tetapi pertumbuhan perusahaan memiliki pengaruh positif signifikan terhadap profitabilitas perusahaan sedangkan Penelitian Pitoyo dan Lestari (2018) pengaruh likuiditas terhadap profitabilitas perusahaan manufaktur yang terdaftar di BEI dimana hasil penelitianya mendapatkan likuiditas yang diproyeksikan dalam rasio lancar tidak berpengaruh terhadap profitabilitas. Hasil penelitian Satria \& Thamrin (2020) pengaruh aktiva tetap dan modal kerja terhadap laba bersih setelah pajak pengahasilan pada perusahaan BUMN dibidang perdagangan (Studi kasus PT. Perusahaan Perdagangan Indonesia (PERSERO), PT. Sarinah (PERSERO) dan Perum Bulog 2012-2016) yang mendapatkan hasil bahwa aktiva tetap berpengaruh negatif signifikan terhadap laba bersih setelah pajak penghasilan, dan modal kerja berpengaruh positif signifikan terhadap laba bersih setelah pajak sedangkann Penelitian Oxtaviana dan Khusbandiyah (2016) pengaruh aktiva tetap, hutang jangka panjang dan perputaran modal kerja terhadap profitabilitas pada perusahaan manufaktur, dengan hasil penelitiannya aktiva tetap dan perputaran modal kerja berpengaruh positif terhadap profitabilitas sedangkan hutang jangka panjang berpengaruh negatif terhadap profitabilitas. Penelitian Juliana \& Melisa (2019) Analisa faktor-faktor yang mempengaruhi profitabilitas perusahaan di indonesia (Studi Kasus: Indek LQ45 periode 2012-2016) dimana hasil penlitiannya ukuran perusahaan berpengaruh negatif dan signifikan terhadap profitabilitas sedangkan variabel umur perusahaan dan rasio kas berpengaruh signifikan terhadap profitabilitas sedangkan pada penelitian Astivasari dan Siswanto (2018) pengaruh struktur modal dan ukuran perusahaan terhadap profitabilitas perusahaan indonesia, dengan hasil penelitiannya mendapatkan bahwa ukuran perusahaan mendapatkan tidak memoderasi pengaruh struktur modal terhadap profitabilitas.

Berikut Fenomena laporan keuangan yang di ambil dari laporan keuangan Bursa Efek Indonesia.

Tabel 1. Sampel Data Likuiditas, Aktiva Tetap dan Ukuran Perusahaan pada perusahaan property and real estate yang terdaftar di Bursa Efek Indonesia periode 2016-2019

\begin{tabular}{|l|l|r|r|r|r|}
\hline \multicolumn{1}{|c|}{$\begin{array}{c}\text { Nama } \\
\text { perusahaa }\end{array}$} & Thn & Utang lancar & \multicolumn{1}{c|}{ Aktiva tetap } & \multicolumn{1}{c|}{ Total aset } & \multicolumn{1}{c|}{ Laba bersih } \\
\hline \multirow{2}{*}{$\begin{array}{l}\text { PT. Alam } \\
\text { Sutera } \\
\text { Realty, Tbk } \\
\text { (ASRI) }\end{array}$} & 2016 & 3.434 .222 .096 & 1.148 .604 .050 & 20.186 .130 .682 & 510.243 .279 \\
\cline { 2 - 6 } & 2017 & 3.143 .479 .123 & 1.225 .363 .874 & 20.728 .430 .487 & 1.385 .189 .177 \\
\cline { 2 - 6 } & 2018 & 2.224 .534 .970 & 1.329 .283 .319 & 20.890 .925 .564 & 970.586 .600 \\
\hline $\begin{array}{l}\text { PT.Bekasi } \\
\text { Asri }\end{array}$ & 2019 & 1.923 .805 .487 & 1.298 .289 .971 & 21.894 .272 .005 & 1.012 .947 .312 \\
\cline { 2 - 6 } $\begin{array}{l}\text { Pemula,Tbk } \\
\text { (BAPA) }\end{array}$ & 2016 & 25.144 .581 .475 & 88.974 .946 & 179.260 .878 .116 & 1.818 .062 .130 \\
\cline { 2 - 6 } & 2018 & 55.374 .100 .820 & 43.196 .422 & 179.035 .974 .052 & 13.212 .381 .915 \\
\cline { 2 - 6 } $\begin{array}{l}\text { PT.Puradelt } \\
\text { a Lestari, }\end{array}$ Tbk & 2019 & 42.887 .324 .516 & 1.277 .381 .264 & 172.313 .437 .729 & 4.874 .818 .808 \\
\cline { 2 - 6 }$($ DMAS) & 2016 & 395.408 .905 .579 & 305.374 .219 .849 & 7.803 .851 .935 .273 & 757.548 .336 .781 \\
\cline { 2 - 6 } & 2018 & 437.801 .866 .027 & 319.501 .561 .830 & 7.470 .941 .557 .319 & 657.119 .635 .819 \\
\cline { 2 - 6 } & 2019 & 1.080 .280 .696 .768 & 309.629 .928 .622 & 7.616 .971 .029 .620 & 1.335 .420 .919 .293 \\
\hline
\end{tabular}

Pada tabel 1 di atas dapat dilihat PT ASRI menunjukkan likuiditas pada utang lancar yang mengalami penurunan dari tahun 2016-2017 sebesar 290.742.973 namun profitabilitas pada laba bersih mengalami kenaikan sebesar 874.945.898. Pada PT BAPA menunjukkan aktiva tetap yang mengalami peningkatan dari tahun 2017-2018 sebesar 1.234.184.842 serta profitabilitas pada laba bersih mengalami peningkatan sebesar 8.337.563.107. Pada PT DMAS menunjukkan ukuran perusahaan pada Total aset yang mengalami peningkatan dari tahun 2018-2019 sebesar 116.937.594.248 serta profitabilitas pada laba bersih mengalami peningkatan sebesar 839.055.948.855. Dapat disimpukan bahwa semakin rendah likuiditas maka tingkat profitabilitas pada perusahaan property and real esate akan mengalami kenaikan, semakin tinggi aktiva maka profitabilitas akan semakin meningkat dan ukuran perusahaan yang tinggi maka akan membuat profitabilitas semakin meningkat pula.

Berdasarkan perbedaan hasil penelitian dan fenomena diatas maka peneliti tertarik 
melakukan penelitian dengan mengambil likuiditas, aktiva tetap dan ukurann perusahaan sebagai variabel independen pada perusahaan property and reak estate yang terdaftar di Bursa Efek Indonesia paeriode 2016-2019.

\section{Rumusan Masalah}

1. Apa pengaruh likuiditas terhadap profitabilitas pada perusahaan property and real estate periode 2016-2019?

2. Apa pengaruh aktiva tetap terhadap profitabilitas pada perusahaan property and real estate periode 2016-2019?

3. Apa pengaruh ukuran perusahaan terhadap profitabilitas perusahaan property and real estate periode 2016-2019?

4. Apa pengaruh likuiditas, aktiva tetap dan ukuran perusahaan terhadap profitabilitas pada perusahaan property and real estate periode 2016-2019?

\section{Tujuan Penelitian}

1. Untuk mengetahui dan menganalisa pengaruh Likuiditas terhadap profitabilitas pada perusahaan property and real estate periode 2016-2019.

2. Untuk mengetahui dan menganalisa pengaruh aktiva tetap terhadap profitabilitas pada perusahaan property and real estate periode 2016-2019.

3. Untuk mengetahui dan menganalisa pengaruh ukuran perusahaan terhadap profitabilitas pada perusahaan property and real estate periode 2016-2019.

4. Untuk mengetahui dan menganalisa pengaruh Likuiditas, aktiva tetap, dan ukuran perusahaan terhadap profitabilitas pada perusahaan property and real estate periode 20162019.

\section{Originalitas Penelitian}

Penelitian ini berdasarkan pengembangan dari peneliti sebelumnya yaitu penelitian oleh Novyanny \& Turangan (2019). Adapun originalitas dalam penelitian kami adalah:

Tabel 2. Originalitas Penelitian

\begin{tabular}{|c|c|c|c|}
\hline $\begin{array}{l}\text { Nama peneliti, Tahun } \\
\text { dan Judul penelitian }\end{array}$ & Persamaan & Perbedaan & $\begin{array}{l}\text { Originalitas } \\
\text { penelitian }\end{array}$ \\
\hline $\begin{array}{lr}\text { Novyanny } & \& \\
\text { Turangan, } & 2019 \\
\text { Pengaruh likuiditas, } \\
\text { ukuran perusahaan, } \\
\text { umur perusahaan dan } \\
\text { pertumbuhan } \\
\text { perusahaan terhadap } \\
\text { profitabilitas pada } \\
\text { perusahaan jasa } \\
\text { sektor perdagangan, } \\
\text { jasa investasi yang } \\
\text { terdaftar pada bursa } \\
\text { efek indonesia. }\end{array}$ & $\begin{array}{l}\text { Variabel } \\
\text { dependen } \\
\text { menggunakan } \\
\text { profitabilitas. } \\
\text { Variabel } \\
\text { independen } \\
\text { menggunakan } \\
\text { likuiditas dan } \\
\text { ukuran } \\
\text { perusahaan. }\end{array}$ & $\begin{array}{l}\text { Pada penelitian } \text { Novyanny \& } \\
\text { Turangan, 2019. Menggunakan } \\
\text { variabel likuiditas, ukuran } \\
\text { perusahaan, umur perusahaan dan } \\
\text { pertumbuhan perusahaan dengan } \\
\text { periode penelitian 2013-2017 dan } \\
\text { menggunakan sektor perdagangan, } \\
\text { jasa investasi. Sedangkan di } \\
\text { penelitian ini kami mengganti umur } \\
\text { perusahaan dan pertumbuhan } \\
\text { perusahaan dengan menjadi aktiva } \\
\text { tetap dan dengan menggunakan } \\
\text { periode 2016-2019 serta sektor yang } \\
\text { digunakan adah subsektor } \\
\text { property and real estate. }\end{array}$ & $\begin{array}{l}\text { Mengganti } \\
\text { variabel } \\
\text { independen } \\
\text { umur perusahaan } \\
\text { dan } \\
\text { pertumbuhan } \\
\text { perusahaan } \\
\text { menjadi aktiva } \\
\text { tetap, mengganti } \\
\text { lokasi penelitian } \\
\text { dan mengupdate } \\
\text { tahun penelitian. }\end{array}$ \\
\hline
\end{tabular}

\section{Rumusan Hipotesis}

1. Likuiditas berpengaruh secara parsial terhadap profitabilitas pada perusahaan property and real estate yang terdaftar di bursa efek indonesia periode 2016-2019.

2. Aktiva tetap berpengaruh secara parsial terhadap profitabilitas pada perusahaan property and real estate yang terdaftar di bursa efek indonesia periode 2016-2019.

3. Ukuran perusahaan berpengaruh secara parsial terhadap profitabilitas pada perusahaan 
property and real estate yang terdaftar di bursa efek indonesia periode 2016-2019.

4. Likuiditas, Aktiva tetap, dan ukuran perusahaan berpengaruh secara simultan terhadap profitabilitas pada perusahaan property and real estate yang terdaftar di bursa efek indonesia periode 2016-2019.

\section{Grand Theory}

Grand Theory yang mendasari penelitian ini adalah signalling theory. Signalling Theory mengemukakan tentang bagaimana seharusnya sebuah perusahaan memberikan sinyal kepada pengguna laporan keuangan. Sinyal ini berupa informasi mengenai apa yang sudah dilakukan oleh manajeman untuk merealisasikan keinginan pemilik (Firmansyah, Rizki 2020). Sinyal dapat berupa promosi atau informasi lain yang menyatakan bahwa perusahaan tersebut lebih baik dari pada perusahaan lain. Teori sinyal menjelasakan bahwa pemberian sinyal dilakukan oleh manajer untuk menguragi asimetri informasi. Dalam hal ini hubungan signalling theory dengan profitabilitas ialah memberikan informasi berupa ROA atau tingkat pengembalian terhadap aset atau sebrapa besar laba yang didapat dari aset yang digunakan. Maka, jika ROA tinggi maka akan menjadi sinyal yang baik bagi para investor. Karena dengan ROA tinggi menunjukkan kinerja keuangan perusahaan tersebut baik maka investor akan tertarik untuk mengivestasikan dananya yang berupa surat berharga atau saham (Sumber: http://www.jurnal.id).

\section{Penelitian terdahulu}

\section{STUDI LITERATUR}

Adapun penelitian terdahulu sebelum penelitian ini adalah :

Tabel 3. Penelitian Terdahulu

\begin{tabular}{|c|c|c|c|c|}
\hline No. & $\begin{array}{l}\text { Nama Peneliti, Tahun } \\
\text { dan Judul Peneliti }\end{array}$ & $\begin{array}{c}\text { Variabel } \\
\text { Dependen dan } \\
\text { Independen }\end{array}$ & Metode Penelitian & Hasil Pe \\
\hline 1 & $\begin{array}{l}\text { Novyanny \& Turangan, } \\
\text { 2019. Pengaruh } \\
\text { likuiditas, ukuran } \\
\text { perusahaan, umur } \\
\text { perusahaan dan } \\
\text { pertumbuhan perusahaan } \\
\text { terhadap profitabilitas } \\
\text { pada perusahaan jasa } \\
\text { sektor perdagangan dan } \\
\text { jasa investasi yang } \\
\text { terdaftar pada Bursa } \\
\text { Efek Indonesia }\end{array}$ & $\begin{array}{l}\text { Variabel } \\
\text { dependen adalah } \\
\text { profitabilitas } \\
\text { dan variabel } \\
\text { independen } \\
\text { adalah } \\
\text { likuiditas, } \\
\text { ukuran } \\
\text { perusahaan, } \\
\text { umur } \\
\text { perusahaan dan } \\
\text { pertumbuhan } \\
\text { perusahaan }\end{array}$ & $\begin{array}{l}\text { Teknik } \\
\text { pengambilan data } \\
\text { menggunakan } \\
\text { analisis regresi } \\
\text { berganda, dengan } \\
\text { menggunakan } \\
\text { metode purposive } \\
\text { sampling, } \\
\text { koefisien } \\
\text { determinasi }\left(\mathrm{R}^{2}\right) \\
\text { serta } \\
\text { menggunakan } \\
\text { statistik } \\
\text { deskriptive. }\end{array}$ & $\begin{array}{l}\text { Variabel likuiditas, } \\
\text { ukuran perusahaan, } \\
\text { dan umur perusahaan } \\
\text { tidak memiliki } \\
\text { pengaruh terhadap } \\
\text { profitabilitas } \\
\text { perusahaan, tetapi } \\
\text { pertumbuhan } \\
\text { perusahaan memiliki } \\
\text { pengaruh positif } \\
\text { signifikan terhadap } \\
\text { profitabilitas } \\
\text { perusahaan. }\end{array}$ \\
\hline 2 & $\begin{array}{l}\text { Satria\& Thamrin, 2020. } \\
\text { Pengaruh aktiva tetap } \\
\text { dan modal kerja terhadap } \\
\text { laba bersih setelah pajak } \\
\text { pengahasilan pada } \\
\text { perusahaan BUMN } \\
\text { dibidang perdagangan } \\
\text { (studi kasus PT. } \\
\text { Perusahaan Perdagangan } \\
\text { Indonesia (PERSERO), } \\
\text { PT. Sarinah (PERSERO) } \\
\text { dan Perum Bulog 2012- } \\
\text { 2016) }\end{array}$ & $\begin{array}{l}\text { Variabel } \\
\text { dependen adalah } \\
\text { laba bersih } \\
\text { setelah pajak } \\
\text { dan variabel } \\
\text { independen } \\
\text { adalah aktiva } \\
\text { tetap dan modal } \\
\text { kerja }\end{array}$ & $\begin{array}{l}\text { Penelitian ini } \\
\text { menggunakan uji } \\
\text { normalitas, } \\
\text { Analisis korelasi } \\
\text { product moment, } \\
\text { analisis korelasi } \\
\text { ganda, analisis } \\
\text { regresi linear } \\
\text { berganda, } \\
\text { koefisien } \\
\text { determinasi, uji t } \\
\text { dan uji F. }\end{array}$ & $\begin{array}{l}\text { Secara parsial aktiva } \\
\text { tetap berpengaruh } \\
\text { negatif signifikan } \\
\text { terhadap laba bersih } \\
\text { setelah pajak } \\
\text { penghasilan, dan } \\
\text { secara pasrial modal } \\
\text { kerja berpengaruh } \\
\text { positif signifikan } \\
\text { terhadap laba bersih } \\
\text { setelah pajak. }\end{array}$ \\
\hline
\end{tabular}




\begin{tabular}{|c|c|c|c|c|}
\hline 3 & $\begin{array}{l}\text { Juliana \& Melisa, } 2019 . \\
\text { Analisa faktor-faktor } \\
\text { yang mempengaruhi } \\
\text { profitabilitas perusahaan } \\
\text { di indonesia (Studi } \\
\text { Kasus: Indek LQ45 } \\
\text { periode 2012-2016) }\end{array}$ & $\begin{array}{l}\text { Variabel } \\
\text { dependen adalah } \\
\text { profitabilitas } \\
\text { dan variabel } \\
\text { independen } \\
\text { adalah ukuran } \\
\text { perusahaan, } \\
\text { umur } \\
\text { perusahaan dan } \\
\text { rasio kas }\end{array}$ & $\begin{array}{l}\text { Penelitian ini } \\
\text { menggunakan } \\
\text { beberapa alat uji } \\
\text { yaitu uji asumsi } \\
\text { klasik, uji regresi } \\
\text { berganda, } \\
\text { koefisien } \\
\text { determinasi }\left(\mathrm{R}^{2}\right) \\
\text { dan uji t secara } \\
\text { parsial }\end{array}$ & $\begin{array}{l}\text { Secara parsial } \\
\text { variabel ukuran } \\
\text { perusahaan } \\
\text { berpengaruh negatif } \\
\text { dan signifikan } \\
\text { terhadap } \\
\text { profitabilitas } \\
\text { sedangkan variabel } \\
\text { umur perusahaan dan } \\
\text { rasio kas } \\
\text { berpengaruh } \\
\text { signifikan terhadap } \\
\text { profitabilitas. }\end{array}$ \\
\hline
\end{tabular}

\section{Landasan Teori \\ Likuiditas}

Kasmir (2017) menyatakan bahwa Likuiditas dalam hal ini menggunakan rasio Rasio lancar (current ratio) merupakan ratio yang digunakan untuk menilai kemampuan perusahaan saat membayar kewajiban jangka pendek yang segera jatuh tempo pada saat diminta secara keseluruhan. Adapun teori yang menjelasakan pengaruh likuiditas terhadap profitabilitas menurut Menurut Umobong \& FCA (2015) likuiditas merupakan " the ability to meet its short-term obligation using its most liquid assets". Kemampuan perusahaan untuk Tepat waktu dalam Mencukupi kebutuhan keuangan yang mengondisikan perusahaan tersebut terlihat baik. Indikator yang digunakan dalam menghitung likuiditas adalah:

\section{Aktiva tetap}

$$
\text { Current Ratio }=\frac{\text { Aktiva Lancar }}{\text { Utang Lancar }}
$$

Kasmir (2017) mengemukakan bahwa aktiva tetap merupakan kekayaan perusahaan yang dimanfaatkan dalam jangka panjang lebih dari satu tahun.Adapun teori yang menjelaskan pengaruh aktiva tetap terhadap profitabilitas menurut Nugraha (2016) adalah Aktiva tetap memungkinkan perusahaan dalam tujuan memudahkan kegiatan produksi yang akan menentukan pendapatan profit yang diinginkan. oleh sebab itu, naik atau turun penentuan aktiva tetap terlalu kuat berpengaruh dalam peningkatan profit. Aktiva ini berfungsi untuk mendukung menjalankan kegiatan yang dilakukan perusahaan dalam rangka memperoleh dana Andari, et. al (2016). Indikator yang digunakan dalam menghitung aktiva tetap menurut Oxtaviana dan Khusbandiyah (2016) adalah

\section{Ukuran Perusahaan}

\section{Aktiva Tetap $=$ Ln Total Aktiva Tetap}

Riadi (2020) menyatakan bahwa ukuran perusahaan merupakan suatu ukuran yang menggambarkan besar kecilnya suatu perusahaan yang dapat dilihat dari total aset perusahaan.Adapun teori yang menjelaskan pengaruh ukuran perusahaan terhadap profitabilitas Menurut Hansen dan Juniarti (2014) perusahaan yang mempunyai ukuran lebih besar akan berpengaruh dalam peningkatan profitabilitas dan nilai perusahaan. Perusahaan yang ukurannya besar mempunyai peluang lebih besar dalam mendapatkan berbagai peluang pendanaan sehingga memudahkan untuk memperoleh pinjaman dari kreditur dengan ukuran yang besar mempunyai profitabilitas yang besar juga (Ratnasari, L. \& Budiyanto 2016). Menurut Seprika, D (2019) Semakin besar ukuran perusahaan berarti asset yang dimiliki pun semakin besar dan dana yang dibutuhkan oleh pihak perusahaan yang bersangkutan mempertahankan kegiatan operasionalnya pun semakin banyak. Indikator yang digunakan Menurut Ratnasari, L. \& Budiyanto (2016) untuk melihat ukuran perusahaan yaitu dengan memakai teori critical resources sebagai berikut :

\section{Size $=$ Ln Total Aset}




\section{Profitabilitas}

Kasmir (2017) menyatakan bahwa rasio profitabilitas merupakan rasio untuk mengukur kinerja perusahaan dalam mencari laba. Rasio ini juga memberikan tingkat efektivitas manajemen suatu perusahaan. Rasio profitabilitas yang dipakai dalam penelitian ini adalah Return On Assets (ROA). Dengan menggunakan rasio ROA maka dapat diketahui seberapa besar tingkat pengambilan investasi yang telah dilakukan perusahaan dengan menggunakan seluruh aktiva yang dimiliki perusahaan. Semakin tinggi ROA semakin tinggi kemampuan perusahaan untuk menghasilkan laba bersih (Novari dan Lestari, 2016).

\section{Populasi Dan Sampel}

\section{METODE}

Pada penelitian ini menggunakan populasi pada perusahaan industri sub sektor property and real estate sebanyak 62 perusahaan dari periode 2016-2019. Jenis teknik pengambilan sampel yang digunakan adalah purposive sampling dimana dalam pengambilan sampelnya harus menurut kriteria atau pertimbangan tertentu (Sujarweni, 2014).

Tabel 4. Kriteria Pengambilan Sampel

\begin{tabular}{|l|c|}
\hline \multicolumn{1}{|c|}{ Keterangan } & Jumlah \\
\hline $\begin{array}{l}\text { Perusahaan jasa sektor property and real estate yang terdaftar di bursa efek } \\
\text { indonesia pada periode 2016-2019 }\end{array}$ & 62 \\
\hline $\begin{array}{l}\text { Perusahaan jasa sektor property and real estate yang terdaftar di bursa efek } \\
\text { indonesia yang tidak memiliki laporan keuangan yang audit pada periode 2016- } \\
2019\end{array}$ & (32) \\
\hline $\begin{array}{l}\text { Perusahaan jasa sektor property and real estate yang terdaftar di bursa efek } \\
\text { indonesia yang yang mengalami kerugian pada periode 2016-2019 }\end{array}$ & (7) \\
\hline \multicolumn{1}{|c|}{ Jumlah perusahaan yang menjadi sampel } & 23 \\
\hline
\end{tabular}

Jadi total sampel yang digunakan dalam penelitian ini adalah 23 perusahaan $\times 4$ tahun pengamatan $=92$ sampel.

\section{Jenis Dan Sumber Data}

Jenis data yang dimanfaatkan dalam penelitian ini yaitu data sekunder. Data sekunder yang diperoleh secara tidak langsung yang dipublikasikan oleh bursa efek indonesia melalui situs www.idx.co.id berupa laporan keuangan perusahaan jasa sektor property and real estate periode 2016-2019.

\section{Teknik Pengumpulan}

Teknik pengumpulan data pada penelitian ini menggunakan dokumentasi. Peneliti menemukan berbagai data penelitian melalui situs internet www.idx.co.id berupa laporan keuangan subsektor industri property and real estate di Bursa Efek Indonesia pada periode 2016-2019.

\section{Koefisien Determinasi}

Ghozali (2018) mengemukakan koefisien determinasi (R2 ) pada intinya mengukur seberapa jauh kemampuan model dalam memaparkan variasi variabel dependen. Nilai koefisien yang digunakan dalam penelitian ini adalah nilai adjusted (R2), nilai adjusted nila determinasi antara nol dan satu.

\section{Model Analisis Data Penelitian}

Model Penelitian metode analisis data yang dipakai adalah metode analisis regresi linier berganda dengan bantuan program SPSS (statistical program and service solution). Analisis ini bertujuan untuk menganalisis besarnya pengaruh dan signifikasi likuiditas, aktiva tetap, dan ukuran perusahaan dengan profitabilitas. 
Owner: Riset \& Jurnal Akuntansi

e-ISSN : 2548-9224 |p-ISSN : 2548-7507

Volume 5 Nomor 2, Agustus 2021

DOI : https://doi.org/10.33395/owner.v5i2.427

\section{Uji t}

Ghozali (2018) mengemukakan bahwa uji statistik t bertujuan untuk memperlihatkan tingkat pengaruh satu variabel penjelas/independen secara individual dalam menerangkan variasi variabel dependen.

Kriteria pengambilan keputusan:

Jika nilai -thitung $<$ ttabel pada $\alpha=5 \%$, maka Ho diterima dan Ha ditolak.

nilai thitung > ttabel atau -thitung <-ttabel pada $\alpha=5 \%$ maka, Ho di tolak dan Ha diterima.

\section{Uji F}

Ghozali (2018) menyatakan bahwa uji statistik F menunjukkan apakah semua variabel independen atau bebas yang dimasukkan pada model memiliki pengaruh secara bersama-sama terhadap variabel dependen/terikat.

Kriteria pengambilan keputusan:

Jika nilai Fhitung $<$ Ftabel pada $\alpha=5 \%$ maka Ho diterima dan Ha ditolak

Jika nilai Fhitung $\geq$ Ftabel pada $\alpha=5 \%$ maka Ho ditolak dan Ha diterima.

\section{Statistik Deskriptif}

\section{HASIL}

Tujuannya memberikan paparan mengenai nilai yang paling sadikit, nilai paling tinggi, total nilai rata-rata dan standar deviasi data yang digunakan dalam penelitian ini. Banyaknya jumlah sampel dalam penelitian ini yaitu 92 data dari 23 perusahaan dengan sampel dikalikan 4 tahun. Berikut data statistik yang diperoleh dalam penelitian ini:

\begin{tabular}{|l|r|r|r|r|r|}
\hline \multicolumn{7}{|c|}{ Tabel 5. Statistic Deskriptif } \\
\hline & N & Minimum & Maximum & Mean & Std. Deviation \\
\hline likuidits (CR) & 92 & 20,990 & 30,110 & 25,36120 & 2,411251 \\
\hline Aktiva tetap & 92 & 14,881 & 29,121 & 23,52021 & 3,922276 \\
\hline Ukuran Prusahaan & 92 & 22,002 & 31,670 & 27,94076 & 2,758474 \\
\hline Profitabilitas (ROA) & 92 &, 0004 & 81,0368 & 1,632704 & 10,7648053 \\
\hline Valid N (listwise) & 92 & & & & \\
\hline
\end{tabular}

Sumber : Data laporan keuangan diolah

\section{Uji Asumsi Klasik}

Uji Normalitas

Pada penelitian ini datanya tidak memenuhi asumsi normalitas dikarenakan nilai signifikan yang diperoleh sebesar $0,000<0,05$ sehingga perlu dilakukan perbaikan data dengan menggunakan transformasi Ln. Statistik non parametrik One Sample Konglomogorov-Smirnov Test (K-S) digunakan dalam penelitian uji normalitas. Adapun Kriteria pengambilan keputusan data berdistribusi normal yaitu :

nilai signifikan $>0,05=$ berdistribusi normal

nilai signifikan $<0,05=$ berditribusi tidak normal

Hasil dari Uji Normalitas sebagai berikut :

\begin{tabular}{|l|l|r|}
\hline \multicolumn{2}{|c|}{ Tabel 6. Uji Normalitas ( One-Sample Kolmogorov-Smirnov Test) } \\
\hline \multicolumn{2}{|c|}{ N } & Unstandardized Residual \\
\hline \multirow{2}{*}{ Normal Parameters ${ }^{\mathrm{a}, \mathrm{b}}$} & Mean & 92 \\
\cline { 2 - 3 } & Std. Deviation &, 0000000 \\
\hline \multirow{2}{*}{ Most Extreme Differences } & Absolute & 1,77577008 \\
\cline { 2 - 3 } & Positive &, 098 \\
\cline { 2 - 3 } & Negative &, 098 \\
\hline Test Statistic &,- 091 \\
\hline Asymp. Sig. (2-tailed) &, 098 \\
\hline
\end{tabular}


Owner: Riset \& Jurnal Akuntansi

e-ISSN : 2548-9224 |p-ISSN : 2548-7507

Volume 5 Nomor 2, Agustus 2021

DOI : https://doi.org/10.33395/owner.v5i2.427

Monte Carlo Sig. (2-tailed)

a. Test distribution is Normal.

\begin{tabular}{|l|r|r|}
\hline Sig. &, $326^{\mathrm{d}}$ \\
\hline \multirow{2}{*}{$99 \%$ Confidence Interval } & Lower Bound &, 314 \\
\cline { 2 - 3 } & Upper Bound &, 338 \\
\hline
\end{tabular}

b. Calculated from data.

Tabel 6 menunjukkan nilai Kolmogorov Smirnov dengan memakai pendekatan monte carlo sig. (2 tailed) sebesar 0,326 dimana nilai signifikan lebih besar dari $0,05(0,326>0,05)$ sehingga dapat disimpulkan bahwa model regresi memenuhi asumsi normalitas.

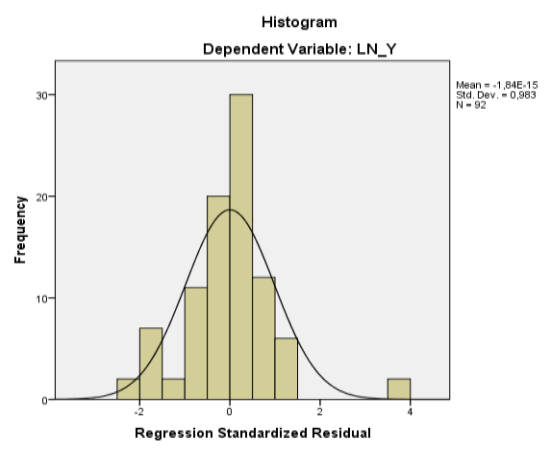

Gambar 1. Grafik Histogram

Gambar 1 grafik histogram menunjukkan setelah dilakukan transformasi data telah memiliki distribusi normal sebab berupa lonceng tidak melenceng ke kiri maupun ke kanan yang berarti menunjukkan bahwa data berdistribusi normal. Selain dari histogram juga bisa dilihat dari grafik P-Plot nya.

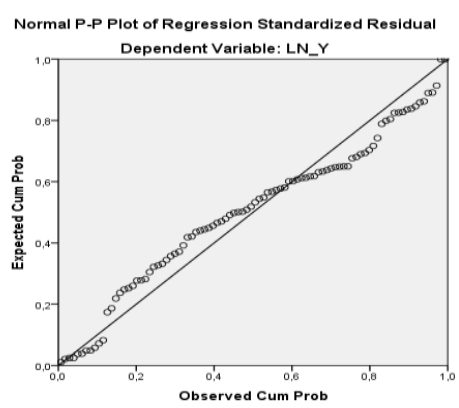

Gambar 2. Grafik P-Plot

Gambar 2 diatas menunjukkan bahwa data residual berdistribusi normal. Dapat dilihat dari titik titik pada grafik normal probability plot yang menyebar di garis diagonal serta mengikuti arah garis diagonal.

\section{Uji Multikoloniaritas}

Bertujuan untuk melihat apakah adanya korelasi antara variabel bebas. Pengujian multikolonieritas dapat dilihat dari tidak adanya nilai tolerance setiap variabel bebas yang kurang dari 0,10 dan tidak ada nilai VIF setiap variabel bebas yang lebih dari 10 .

\begin{tabular}{|c|c|c|c|c|c|c|}
\hline \multicolumn{7}{|c|}{ Tabel 7. Uji Multikoloniaritas } \\
\hline & $\begin{array}{c}\text { Unstandardized } \\
\text { Coefficients }\end{array}$ & \multirow{2}{*}{$\begin{array}{c}\text { Standardized } \\
\text { Coefficients } \\
\text { Beta } \\
\end{array}$} & \multirow[b]{2}{*}{$\mathrm{t}$} & \multirow[b]{2}{*}{ Sig. } & \multicolumn{2}{|c|}{$\begin{array}{c}\text { Collinearity } \\
\text { Statistics }\end{array}$} \\
\hline Model & Std. Error & & & & Tolerance & VIF \\
\hline \multirow[t]{3}{*}{1} & 9,001 & & 2,034 & ,045 & & \\
\hline & 1,983 &,- 068 &,- 672 & ,503 & ,998 & 1,002 \\
\hline & 1,244 &,- 026 &,- 216 & ,830 & ,724 & 1,381 \\
\hline
\end{tabular}


Owner: Riset \& Jurnal Akuntansi

e-ISSN : 2548-9224 |p-ISSN : 2548-7507

Volume 5 Nomor 2, Agustus 2021

DOI : https://doi.org/10.33395/owner.v5i2.427

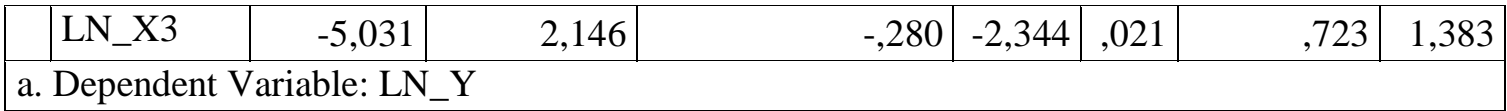

Berdasarkan tabel 7 di atas menunjukkan bahwa tidak terjadi gejala multikoloniaritas antara variabel independen dibuktikan dengan tidak ada nilai Tolerance yang kurang dari 0,10 dan tidak ada nilai VIF (variance inflation factor) yang lebih besar dari 10.

\section{Uji Autokorelasi}

Penelitin ini untuk mengetahui adanya korelasi di model regresi linear. Hasil uji autokorelasi dapat dilihat dari besaran Durbin Watson (D-W) dengan memakai pendekatan Chorchare-Orcut.

\begin{tabular}{|l|c|r|r|r|r|}
\hline \multicolumn{7}{|c|}{ Tabel 8.Uji Autokorelasi (Chorchare- Orcut) } \\
\hline Model & $\mathrm{R}$ & R Square & Adjusted R Square & Std. Error of the Estimate & Durbin-Watson \\
\hline 1 &, $367^{\mathrm{a}}$ &, 135 &, 105 & 1,46440 & 1,779 \\
\hline a. Predictors: (Constant), lag_x3, lag_x1, lag_x2 \\
\hline
\end{tabular}

Berdasarkan table 8 menunjukkan perolehan nilai statistik D-W dari pengolahan data dengan menggunakan uji Chorchare- Orcut sebesar 1,779 dan dalam tabel D-W untuk "K"= 3 dan N =92 besar nilai dl (batas bawah) $=1,5941$ dan du (batas atas) $=1,7285 ; 4-\mathrm{dl}=2,4059$ dan $4-\mathrm{du}=$ 2,2715. Dalam kriteria durbin watson dimana nilai $\mathrm{du}<\mathrm{dw}<4$-du atau 1,7285 < 1,779 <2,2715. Maka dari hasil uji autokorelasi dapat diambil kesimpulan bahwa tidak terjadi gejala autokorelasi.

\section{Uji Heterokedastisitas}

Uji heterokedastisitas adalah uji yang menilai apakah adanya perbedaan varian dari residual untuk semua pengamatan pada model regresi linear.

\begin{tabular}{|c|c|c|c|c|c|c|}
\hline \multicolumn{7}{|c|}{ Tabel 9. Uji Glejser } \\
\hline & & \multicolumn{2}{|c|}{ Unstandardized Coefficients } & \multirow{2}{*}{$\begin{array}{c}\text { Standardized } \\
\text { Coefficients }\end{array}$} & \multirow[b]{2}{*}{$\mathrm{t}$} & \multirow[b]{2}{*}{ Sig. } \\
\hline \multicolumn{2}{|c|}{ Model } & $\mathrm{B}$ & Std. Error & & & \\
\hline \multirow[t]{4}{*}{1} & (Constant) & .479 & 6,321 & & .076 & 940 \\
\hline & LN_CR & 901 & 1,393 &, 068 & 647 &, 519 \\
\hline & LN_FA & 1,281 &, 873 & 181 & 1,466 & 146 \\
\hline & LN_FS & $-1,858$ & 1,507 &,- 152 & $-1,232$ & 221 \\
\hline
\end{tabular}

Berdasarkan tabel 9 menunjukkan bahwa didalam analisis regresi tidak terjadi gejala heterokedastisitas. Ditunjukkan dengan nilai signifikansi variabel independen likuiditas (CR) yang sebesar 0,519, aktiva tetap sebesar 0,146 dan ukuran perusan sebesar 0,221. Hasil tersebut menjelaskan bahwa tidak ada satupun variabel independen yang signifikansi secara statistik mempengaruhi variabel dependen. Hal tersebut dikarenakan nilai propabilitas signifikansinya yang di atas 0,05 .

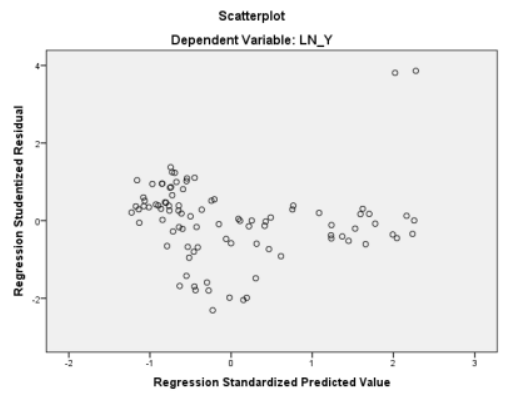

Gambar 3.Uji Heterokedastisitas Scatterplot 
Gambar 3 menunjukkan adanya titik-titik yang menyebar sembarang baik di atas maupun dibawah angka 0 pada sumbu Y. Hal ini berarti tidak terdapat adanya gejela heterokedastisitas.

\section{Hasil Analisis Data Penelitian Analisis Regresi Linear Berganda}

\begin{tabular}{|c|c|c|c|c|c|}
\hline \multicolumn{6}{|c|}{$\begin{array}{l}\text { Tabel 10. Analisis Regresi Linear Berganda } \\
\text { Coefficients }{ }^{a}\end{array}$} \\
\hline \multirow[b]{2}{*}{ Model } & \multicolumn{2}{|c|}{ Unstandardized Coefficients } & \multirow{2}{*}{$\frac{\text { Standardized Coefficients }}{\text { Beta }}$} & \multirow[b]{2}{*}{$\mathrm{t}$} & \multirow[b]{2}{*}{ Sig. } \\
\hline & B & Std. Error & & & \\
\hline \begin{tabular}{l|l}
1 & (Constant)
\end{tabular} & 18,310 & 9,001 & & 2,034 & 045 \\
\hline LN_X1 & $-1,332$ & 1,983 &,- 068 &,- 672 & ,503 \\
\hline LN_X2 &,- 268 & 1,244 &,- 026 &,- 216 & 830 \\
\hline LN_X3 & $-5,031$ & 2,146 &,- 280 & $-2,344$ & ,021 \\
\hline a. Dependent & Variable: LN & & & & \\
\hline
\end{tabular}

Cara menghitung regresi linear berganda pada penelitian ini yaitu:

LN_ROA $=18,310-1,332$ LN_CR - 0,268 LN_Aktiva Tetap - 5,031 LN_Ukuran Perusahaan

1. Konstanta sebesar 18,310 yang artinya apabila likuiditas, aktiva tetap dan ukuran perusahaan dianggap konstan, maka nilai profitabilitas pada perusahaan property and real estate sebesar 18,310 .

2. Likuiditas (Ln_X1) dengan b1 sebesar -1,332 artinya ketika likuiditas mengalami kenaikan sebesar 1 satuan maka profitabilitas mengalami penurunan sebesar 1,332.

3. Aktiva tetap (Ln_X2) dengan b2 sebesar $-0,268$ artinya ketika aktiva tetap mengalami kenaikan sebesar 1 satuan maka profitabilitas mengalami penurunan sebesar 0,268.

4. Ukuran Perusahaan (Ln_X3) dengan b3 sebesar -5,031 artinya ketika ukuran perusahaan mengalami kenaikan sebesar 1 satuan maka profitabilitas mengalami penurunan sebesar 5,031 .

\section{Koefisien Determinasi}

Koefisien determinasi bertujuan untuk melihat seberapa besarnya kemampuan variabel bebas dalam menjelaskan variabet terikat. Besarnya pengaruh variabel $\mathrm{X}$ terhadap variabel $\mathrm{Y}$ bisa dilihat melalui adjusted $\mathrm{R} 2$ square sebagai berikut:

\begin{tabular}{|l|c|r|c|c|}
\hline \multicolumn{5}{|c|}{ Tabel 11. Koefisien Determinasi } \\
\hline Model & R & R Square & $\begin{array}{c}\text { Adjusted R } \\
\text { Square }\end{array}$ & $\begin{array}{c}\text { Std. Error of } \\
\text { the Estimate }\end{array}$ \\
\hline 1 &, $300^{\text {a }}$ &, 090 &, 059 & 1,80579 \\
\hline \multicolumn{5}{|l|}{ a. Predictors: (Constant), LN_X3, LN_X1, LN_X2 } \\
\hline \multicolumn{4}{|l}{ b. Dependent Variable: LN_Y } \\
\hline
\end{tabular}

Berdasarkan tabel 11 yang menunjukkan variasi dari variabel independen terikat dilihat dari besarnya nilai adjusted $R$ square adalah 0,059 yang berarti sebesar 5,9 \% variasi variabel profitabilitas (Y) dapat dijelasakan oleh variabel likuiditas (X1), aktiva tetap (X2), Ukuran perusahaan (X3) dimana sisanya sebesar 94,1\% merupakan variasi variabel lain yang tidak di jelaskan dalam penelitian ini.

\section{Pengujian Hipotesis Secara Simultan}

Uji $\mathrm{F}$ digunakan untuk menjelaskan apakah semua variabel independent mempunyai pengaruh secara bersama-sama terhadap variabel dependen. Berikut hasil pengolahan data dengan program SPS 


\begin{tabular}{|c|c|c|c|c|c|}
\hline \multicolumn{6}{|c|}{$\begin{array}{l}\text { Tabel 12. Uji F } \\
\text { ANOVA }\end{array}$} \\
\hline Model & Sum of Squares & $\mathrm{df}$ & Mean Square & $\mathrm{F}$ & Sig. \\
\hline \begin{tabular}{l|l|}
1 & Regression \\
\end{tabular} & 28,365 & 3 & 9,455 & 2,900 &, $039^{\mathrm{b}}$ \\
\hline Residual & 286,956 & 88 & 3,261 & & \\
\hline Total & 315,321 & 91 & & & \\
\hline \multicolumn{6}{|c|}{ a. Dependent Variable: LN_Y } \\
\hline \multicolumn{6}{|c|}{ b. Predictors: (Constant), LN_ } \\
\hline
\end{tabular}

Berdasarkan tabel 12 di atas dapat dilihat bahwa secara bersama-sama variabel independen berpengaruh serta signifikan terhadap depeden. Hasil uji statistik F menghasilkan nilai Fhitung sebesar 2,900. Sementara dengan perhitungan Ftabel $=\mathrm{k} ; \mathrm{n}-\mathrm{k}=(3 ; 92-3)=(3 ; 89)=2,71$ jadi diperoleh nilai $\mathrm{F}$ tabel sebesar 2,71 dengan nilai signifikansi dibawah 0,05 yaitu sebesar 0,039. Hasil dari statistik Uji F menunjukkan bahwa nilai Fhitung > Ftabel $(2,900>2,71)$ dengan perolehan nilai signifikan sebesar 0,039 yang berarti Ha diterima Ho ditolak. Hal ini menunjukkan bahwa likuiditas, aktiva tetap, ukuran perusahaan secara simultan berpengaruh signifikan terhadap profitabilitas pada perusahaan property and real estate yang terdaftar di Bursa Efek Indonesia periode 2016 -2019.

\section{Pengujian Hipotesis Secara Parsial}

Uji T digunakan untuk melihat seberapa jauh pengaruh variabel independent terhadap variabel dependen secara parsial. Hasil pengujian dengan uji $\mathrm{T}$ adalah sebagai berikut :

\begin{tabular}{|c|c|c|c|c|c|}
\hline \multicolumn{6}{|c|}{ Tabel 13. Uji T } \\
\hline \multirow[b]{2}{*}{ Model } & \multicolumn{2}{|c|}{ Unstandardized Coefficients } & \multirow{2}{*}{\begin{tabular}{|c|} 
Standardized Coefficients \\
Beta
\end{tabular}} & \multirow[b]{2}{*}{$\mathrm{t}$} & \multirow[b]{2}{*}{ Sig. } \\
\hline & B & Std. Error & & & \\
\hline 1 (Constant) & 18,310 & 9,001 & & 2,034 &, 045 \\
\hline LN_X1 & $-1,332$ & 1,983 &,- 068 &,- 672 & ,503 \\
\hline LN_X2 &,- 268 & 1,244 &,- 026 &,- 216 &, 830 \\
\hline LN_X3 & $-5,031$ & 2,146 &,- 280 & $-2,344$ &, 021 \\
\hline
\end{tabular}

Berdasarkan tabel 13 diatas nilai Ttabel untuk di ambil dengan menggunakan rumus $(\alpha / 2$; $\mathrm{n}-\mathrm{k}-1)=(0,05 / 2 ; 92-3-1)=0,025 ; 88$, jadi Ttabel adalah 1,98729 . Dengan demikian hasil dari uji $\mathrm{T}$ dapat dijelaskan sebagai berikut :

1. Hasil perhitungan uji T secara parsial pada likuiditas diperoeh nilai -Thitung sebesar -0,672 dan Ttabel sebesar 1,98729 atau -Thitung < Ttabel $(-0,672<1,98729)$ dengan nilai signifikansi 0,503 > 0,05 maka Ha ditolak dan Ho diterima artinya secara parsial likuiditas tidak berpengaruh signifikan terhadap profitabilitas pada pada perusahaan property andreal estate yang terdaftar di Bursa Efek Indonesia periode 2016-2019.

2. Hasil perhitugan uji $\mathrm{T}$ secara parsial pada aktiva tetap diperoleh nilai -Thitung sebesar 0,216 dan Ttabel sebesar 1,98729 atau -Thitung < Ttabel $(-0,216<1,98729)$ dengan nilai signifikan 0,830 > 0,05 maka Ha ditolak dan Ho diterima artinya secara parsial aktiva tetap tidak berpengaruh signifikan terhadap profitabilitas pada pada perusahaan property and real estate yang terdaftar di Bursa Efek Indonesia periode 2016-2019.

3. Hasil uji T secara parsial pada ukuran perusahaan diperoleh nilai Thitung sebesar $-2,344$ dan -Ttabel sebesar -1,98729 atau -Thitung < -Ttabel $(-2,344<-1,98729)$ dengan nilai signifikan 0,021 $<0,05$ maka Ha diterima dan Ho ditolak artinya secara parsial ukuran perusahaan berpengaruh negatif dan signifikan terhadap profitabilitas pada pada perusahaan property and real estate yang terdaftar di Bursa Efek Indonesia periode 20162019. 


\section{PEMBAHASAN}

Berdasarkan teori seperti yang dijelaskan Umobong \& FCA (2015) likuiditas merupakan Kemampuan perusahaan untuk Tepat waktu dalam mencukupi kebutuhan keuangan yang mengondisikan perusahaan tersebut terlihat baik. Ternyata dalam penelitian ini memberikan hasil bahwa secara parsial likuiditas yang di proyeksi dengan current ratio tidak berpengaruh signifikan terhadap profitabilitas pada pada perusahaan property and real estate. Artinya likuiditas tidak berpengaruh signifikan terhadap profitabilitas dikarenakan nilai aktiva lancar yang terlalu tinggi. Aktiva lancar yang memiliki nilai yang terlalu tinggi tidak menjamin perusahaan tersebut akan baik. semakin tinggi aktiva lancar menyebabkan sebagian modal kerja perusahaan tidak berputar atau mengalami pengganguran sehingga dapat mengurangi kemampuan perusahaan dalam memperoleh laba. Hal ini didukung oleh penelitian Laura (2015) dan Novyanny \& Turangan (2017) bahwa likuiditas tidak berpengaruh signifikan terhadap profitabilitas.

Berdasarkan teori yang diungkapkakn Nugraha (2016) bahwa Aktiva tetap memungkinkan perusahaan dalam tujuan memudahkan kegiatan produksi yang akan menentukan pendapatan profit yang diinginkan. Ternyata Berdasarkan hasil penelitian menunjukkan bahwa secara parsial aktiva tetap tidak berpengaruh signifikan terhadap profitabilitas pada pada perusahaan property and real estate. Variabel aktiva tetap yang tidak berpengaruh secara signifikan dibuktikan karena perusahaan property and real estate menggunakan berbagai dana yang besar untuk digunakan dalam pembelian investasi aktiva tetap perusahaan dan akibatnya menimbulkan pengeluaran pada kas yang mengakibatkan profitabilitas perusahaan property and real estate akan menurun. Hal ini menunjukkan bahwa semakin besar aktiva tetap dalam perusahaan property and real estate maka semakin kecil profitabilitas. Akan tetapi Hasil penelitian ini sejalan dengan penelitian $\underline{\text { Satria \& }}$ Thamrin (2020). dimana hasilnya menunjukkan bahwa aktiva tetap tidak berpengaruh signifikan terhadap profitabilitas.

Berdasarkan teori pengaruh seperti yang dijelaskan Hansen dan Juniarti (2014) perusahaan yang mempunyai ukuran lebih besar akan berpengaruh dalam peningkatan profitabilitas dan nilai perusahaan. Teori diatas sejalan dengan penelitian ini dimana secara parsial ukuran perusahaan berpengaruh negatif dan signifikan terhadap profitabilitas pada pada perusahaan property and real estate. Hal ini menunjukkan dengan adanya hubungan negatif antara ukuran perusahaan dengan profitabilitas maka dapat disimpulkan semakin kecil ukuran perusahaan maka kemampuan perusahaan dalam menghasilkan profit atau laba pada perusahaan akan menurun. Pengaruh signifikan pada penelitian ini menunjukkan bahwa perusahaan dengan aset yang besar maka penggunaan sumber daya yang ada akan bisa digunakan secara makimal dan juga efisien untuk memperoleh keuntungan. Penelitian ini juga didukung oleh penelitian Juliana dan Melisa (2019) dimana variabel ukuran perusahaan memiliki pengaruh negatif dan signifikan terhadap profitabilitas.

\section{KESIMPULAN}

Berdasarkan hasil penelitian mengenai pengaruh likuiditas (CR), aktiva tetap, dan ukuran terhadap profitabilitas (ROA) Pada perusahaan property and real estate yang Terdaftar Di Bursa Efek Indonesia Periode 2016-2019 maka bisa diambil kesimpulan bahwa Secara parsial likuiditas tidak berpengaruh signifikan terhadap profitabilitas pada perusahaan property and real estate yang terdaftar di Bursa Efek Indonesia periode 2016-2019. Secara parsial aktiva tetap tidak berpengaruh signifikan terhadap profitabilitas pada perusahaan property and real estate yang terdaftar di Bursa Efek Indonesia periode 2016-2019. Secara parsial ukuran perusahaan berpengaruh negatif dan signifikan terhadap profitabilitas pada perusahaan property and real estate yang terdaftar di Bursa Efek Indonesia periode 2016-2019 Dan Secara simultan bahwa likuiditas, aktiva tetap, ukuran perusahaan berpengaruh positif signifikan terhadap profitabilitas pada perusahaan property and real estate yang terdaftar di Bursa Efek Indonesia periode 2016-2019.

\section{REFERENSI}

Andari, Y., Rina, A., \& Rita, A. (2016). Pengaruh Perputaran Barang Jadi, Arus Kas,Piutang dan Aktiva Tetap terhadap Profitabilitas pada Perusahaan Perdagangan Eceran Yang terdaftar di BEI Periode 2009-2014. Journal of Accounting, 2(2), 6. http://jurnal.unpand.ac.id/index.php/AKS/article/download/474/460 
Astivasari, N., \& Siswanto, E. (2018). Pengaruh Struktur Modal dan Ukuran Perusahaan Terhadap Profitabilitas Perusahaan Indonesia (Studi Pada Perusahaan Sektor Property and Real Estate yang Listing di BEI Periode 2012-2014). Ekonomi Bisnis, 23(1), 35. https://doi.org/10.17977/um042v23i1p35-42

Firmansyah, Rizki (2020, 27 November). Teori Sinyal (Signalling Theory) diakses dari https://wwwkompasiana-com.cdn.ampproject.org/v/s/www.kompasiana .com/amp/rizkifirmansyah6995/5fc064104b222b7192574782/teori-sinyal-signalling-theory

Ghozali, Imam, 2018. Aplikasi Analisis Multivariete Dengan Program - IBM SPSS 23. Cetakan Ke-8. Semarang :Universitas Diponegoro.

Hansen, V. Dan Juniarti, (2014) Pengaruh Family Control, Size, Sales Growth Dan Leverage Terhadap Profitabilitas Dan Nilai Perusahaan Pada Sektor Perdagangan, Jasa Dan Investasi. Jurnal Bussiness Acounting Review.

Juliana, A., \& Melisa, M. (2019). ANALISA FAKTOR-FAKTOR YANG MEMPENGARUHI PROFITABILITAS PERUSAHAAN DI INDONESIA (Studi Kasus: Indek LQ45 Periode 20122016). Managament Insight: Jurnal Ilmiah Manajemen, 13(1), 36-50.

Kasmir, K., 2017. Analisis Laporan Keuangan. Edisi 1-5 ,Cetakan Ke-5, Jakarta : Rajawali Pers.

Laura, Maria, 2015. Analisis Pengaruh Likuiditas Dan Leverage Terhadap Profitabilitas Pada Pt. Fast Food Indonesia, Tbk Yang Terdaftar Di Bursa Efek Indonesia.

Novari, P., \& Lestari, P. (2016). Pengaruh Ukuran Perusahaan, Leverage, Dan Profitabilitas Terhadap Nilai Perusahaan Pada Sektor Properti Dan Real Estate. E-Jurnal Manajemen Universitas Udayana, 5(9), 252428.

Novyanny, M. C., \& Turangan, J. A. (2017). Pengaruh Likuiditas, Ukuran Perusahaan, Umur Perusahaan dan Pertumbuhan Perusahaan Terhadap Profitabilitas Pada Perusahaan Jasa Terdaftar Pada Bursa Efek Indonesia. Journal of Management Studies, 4(1), 66-78.

Nugraha, Ogi Wahyu, 2016. Pengaruh Aktiva Tetap, Hutang Jangka Panjang Dan Modal Terhadap Profitabilitas Pada Pt.Pindad (Persero).

Oxtaviana, T. A., \& Khusbandiyah, A. (2016). Pengaruh Aktiva Tetap, Hutang Jangka Panjang Dan Perputaran Modal Kerja Terhadap Profitabilitas Pada Perusahaan Manufaktur Yang Terdaftar Di Bursa Efek Indonesia. Fakultas Ekonomi Dan Bisnis Universitas Muhammadiyah Purwokerto.

Pitoyo, M. M., \& Lestari, H. S. (2018). Pengaruh likuiditas terhadap profitabilitas perusahaan manufaktur yang terdaftar di Bursa Efek Indonesia. Fakultas Ekonomi dan Bisnis Universitas Trisakti, Jakarta. Vol. 13 No.1.

Pujayanti, A. (2018). Perang Dagang Amerika Serikat-China dan Implikasinya bagi Indonesia. Info Singkat: Bidang Hubungan Internasional, X(07/I/Puslit/April/2018), 7-12.

http://berkas.dpr.go.id/puslit/files/info_singkat/Info Singkat-X-7-I-P3DI-April-2018-179.pdf

Ratnasari, L., \& Budiyanto. (2016). Pengaruh Leverage, Likuiditas, Ukuran Perusahaan Terhadap Profitabilitas Pada Perusahaan Otomotif Di Bei. Ilmu Dan Riset Manajemen, 5(6), 1-15.

Riadi, Muchlisin. (2020, 24 April) Ukuran perusahaan (Pengertian, Jenis, Kriteria dan Indikator) Diakses dari https: //www.kajianpustaka.com/2020/04/ukuran-perusahaan-penegrtian-jeniskriteria-dan-indikator.html?m=1

Satria, M. R., \& Thamrin, T. A. N. (2020). Pengaruh Aktiva Tetap Dan Modal Kerja Terhadap Laba Bersih Setelah Pajak Penghasilan Pada Perusahaan BUMN Dibidang Perdagangan (Studi Kasus PT. Perusahaan Perdagangan Indonesia, PT. Sarinah, Dan Perum Bulog) 2012-2016. Land Journal, 1(1), 1-107.

Seprika, D. (2019). Profitabilitas Yang Dipengaruhi Ukuran Perusahaan,Modal Kerja Dan Perputaran Piutang (Survei) Pada Perusahaan Sub Sektor Property And Real Estate Yang Terdaftar Di BEI Periode 2014-2018).

Sujarweni, V. Wiratna, 2014. Metodologi Penelitian. Cetakan Ke-1. Yogyakarta : Pustaka Baru Press.

Umobong, A. A., \& FCA. (2015). Assessing the Impact of Liquidity and Profitability Ratios on Growth of Profits in Pharmaceutical Firms in Nigeria. European Journal of Accounting, Auditing and Finance Research, 3(10), 97-114.

http://www.idx.co.id

http://www.jurnal.id 